\title{
Formation of Protein Corona on Rhodium Citrate-Functionalized Magnetic Nanoparticles and Their Interaction with Human Macrophages
}

\author{
Weskly F Lago ${ }^{1}$, Natália V de Carvalho², Natália L Chaves ${ }^{3}$, Marina A Radicchi ${ }^{4}$, Marcelo H Sousa ${ }^{5}$, Wagner \\ Fontes $^{2}$, Marcelo Valle de Sousa ${ }^{2}$ and Sônia Nair Báo ${ }^{2 *}$
}

${ }^{1}$ Nanoscience and Nanobiotechnology Program, Institute of Biological Sciences, University of Brasilia, Brazil; ${ }^{2}$ Department of Cell Biology, Institute of Biological Sciences, University of Brasilia, Brazil; ${ }^{3}$ Animal Biology Program, Institute of Biological Sciences, University of Brasilia, Brazil; ${ }^{4}$ Molecular Biology Program, Institute of Biological Sciences, University of Brasilia, Brazil; ${ }^{5}$ Green Nanotechnology Group, University of Brasilia, Brazil

\begin{abstract}
Nanoscience and Nanotechnology enable innovations for Medicine and for Biomedical Science. Among the current nanoparticles, maghemite associated with rhodium citrate (Magh-RhCit) has been shown to be promising, because it reduces side effects of drugs while maintaining cytotoxicity for tumor cells. However, NPs in contact with biological fluids are immediately coated by proteins (protein corona) that are unique to each nanomaterial. In this study, the adsorption of the most abundant binding proteins was studied in vitro using a three-step analysis: (1) characterization of the magnetic fluid (Magh-RhCit) before and after incubation with serum; (2) identification and physical and biochemical analysis of protein corona; and (3) the cellular internalization of these nanoparticles in human macrophages. Magh-RhCit was initially obtained in the magnetite phase $\left(\mathrm{Fe}_{3} \mathrm{O}_{4}\right)$ via alkaline coprecipitation of $\mathrm{Fe}^{2+}$ and $\mathrm{Fe}^{3+}$ ions and subsequently oxidized to maghemite by the bubbling of oxygen gas in the suspension. Later, rhodium citrate was associated with nanoparticles. Dynamic Light Scattering data were used for characterization of the hydrodynamic diameter and zeta potential. The morphological characterization and measurement of the particles were obtained from Scanning and Transmission Electron Microscopy, and the X-ray Diffraction technique. The identification of the proteins was performed by Liquid Chromatograph coupled to Mass Spectrometry. Human blood serum altered the characteristics of the nanoparticle, making it less polydisperse, larger and with less negative zeta potential, indicating the formation of the protein corona. Forty-nine proteins (which mostly promote opsonization, phagocytosis and endocytosis in cells of the immune system) were identified and characterized: albumin, IgGs, apoliproteins, serpins, complement (C5), kinases, haptoglobin, glycoproteins and transferrin. Nanoparticle characterization and mass spectrometric data of the digested protein corona suggest improved biocompatibility. Moreover, results regarding nanoparticles' interaction with macrophages suggest that the corona may have profoun implications for in vitro and in vivo extrapolations and will require some consideration in the future.
\end{abstract}

Keywords: Rhodium citrate; Magnetic nanoparticles; Protein corona; U-937; Macrophage

\section{INTRODUCTION}

The development of nanotechnology in the search for high selectivity and affinity of substances to their pharmacological targets has optimized the use of nanomaterials as therapeutic and diagnostic agents for applications in the biomedical and biotechnological area [1]. The effectiveness of the use of nanocarriers in the drug delivery system depends entirely on physico-chemical characterization, such as particle size, surface charge, density, surface topography, physiological condition of the target site [2] and its interaction with biological fluids [1].

Magnetic nanoparticles, due to their multifunctional properties, are potentially applicable in the biomedical area, considering the magnetic, electrical and optical properties, biocompatibility and stability of their composition, their tunable morphology, functionalization and bioavailability of the compound in the organism [3,4]. These nanoparticles (NPs) can be used as contrast

Correspondence to: Sônia Nair Báo, Department of Cell Biology, Institute of Biological Sciences, University of Brasília, Brazil, Tel: +55 61 3107 2978 ;

E-mail: snbao@unb.br

Received: July 30, 2019, Accepted: August 12, 2019, Published: August 16, 2019

Citation: Lago WF, de Carvalho NV, Chaves NL, Radicchi MA, Sousa MH, Fontes W, et al. (2019) Formation of Protein Corona on Rhodium Citrate-Functionalized Magnetic Nanoparticles and their Interaction with Human Macrophages. J Nanomed Nanotech. 10:534. doi: 10.35248/21577439.19.10.533

Copyright: (c) 2019 Lago WF, et al. This is an open-access article distributed under the terms of the Creative Commons Attribution License, which permits unrestricted use, distribution, and reproduction in any medium, provided the original author and source are credited. 
agents in magnetic resonance, in photodynamic therapy, in the treatment of hyperthermia of cancer cells, as biosensors, bioseparators and vehicles in the drug delivery system, in order to lower systemic toxicity [5-7].

However, one of the major problems encountered is the fact that the mononuclear phagocytic system and the renal system compete with NPs for the tumor, and sequester and/or eliminate $99 \%$ of the NPs administered. The mononuclear phagocytic system consists primarily of the liver, spleen, lymph nodes, bone marrow, skin, and other organs that contain resident phagocytic cells, such as macrophages $[8,9]$.

When NPs are administered in biological systems they interact with the components present in the physiological environment [1], being exposed to species of biomolecules and substances that result in the formation of the biological corona [10]. The complexes formed by the interaction of NPs and proteins form the biological component of the protein corona (PC) [1,11-14], which has a dynamic composition defined by complex interactions that depend on colloidal forces, as well as dynamic physicochemical characteristics of the particle $[10,14]$. PC formation induces changes in the nature of the extracellular matrix of the NP, altering the original biological identity $[7,10,11,15]$. In this context, the adsorbed proteins control the cellular interaction receptors, coordinate the internalization pathway and modulate the immune response, such as the macrophage uptake, complement system activation and cellular toxicity $[10,11,14,16,17]$.

The absorption of NPs by macrophages varies based on the serum proteins that opsonize them [18] and although the biological fluids contain a great variety of proteins, the PC composition is unique for each nanomaterial and is influenced by several parameters such as the nanoparticle chemistry and environmental characteristics [19].

Previous studies with maghemite NPs and maghemite NPs functionalized with rhodium (II) citrate (Magh-RhCit) showed progress and great potential for chemotherapeutic treatment [7,2024]. However, as yet there are no studies related to the identification of the protein corona of this NP nor about its interaction in cells of the immune system. In this study, adsorption of the most abundant binding proteins was performed in vitro after incubation of less polydisperse NPs in human blood serum using a three-step analysis: (1) characterization of magnetic fluid (Magh-RhCit) before and after incubation with the serum; (2) characterization of the protein corona; and (3) evaluation of the influence of the protein corona in the internalization of the NPs by macrophages derived from the leukemic human lymphocyte cell line, U-937.

\section{MATERIALS AND METHODS}

\section{Materials}

The materials used to conduct this study were iron(III) chloride hexahydrate $\left(\mathrm{FeCl}_{3} \cdot 6 \mathrm{H}_{2} \mathrm{O}\right)$, iron(II) chloride tetrahydrate $\left(\mathrm{FeCl}_{2} \cdot 4 \mathrm{H}_{2} \mathrm{O}\right)$, sodium hydroxide $(\mathrm{NaOH})$, nitric acid $\left(\mathrm{HNO}_{3}\right)$, rhodium (II) trifluoroacetate dimer, Tripan blue, Dimethyl Sulfoxide (DMSO), antibiotic solution (penicillin and streptomycin), phorbol 12-myristate 13-acetate (PMA), bicarbonate (PA), Iodocetamide (IAA) and Empore ${ }^{\text {TM }}$ Solid Phase Extraction Disks -C18 (Octadecyl) - Sigma-Aldrich ${ }^{\circledR}$, USA; Modified RPMI-1640 Medium, Fetal Bovine Serum (SFB), Trypsin $0.25 \%$ in EDTA - GIBCO, USA; Paraformaldehyde 37\% - Vetec, Brazil; 3-(4,5-Dimethylthiazol-2-Yl)-
2,5-Diphenyltetrazolium Bromide (MTT) - Molecular Probes, USA; CD14 monoclonal antibody (TUK4), APC-alexa fluor $7500.5 \mathrm{~m}$, kit Qubit@ 2.0 Fluorometer, Guanidine - Invitrogen/Life/Thermo Scientific, USA; Ethanol, ethyl acetate, methanol, Petroleum ether - Dinâmica, Brazil; Tampão fosfato salino (PBS) - Laborclin, Brazil; DTT - GE Healthacare Life Science, USA; AcetonitrilE - Fluka; HCCA Matrix - Bruker, Germany; Dr Spurr Resin, glutaraldehyde, uranyl acetate, osmium tetroxide, potassium ferricyanide - Electron Microscopy, USA.

\section{Obtaining serum and whole human blood}

After the approval of the project by the Research Ethics Committee (CAAE: 59103416.9.0000.0030; Number: 1,936,932), 20 samples of whole human blood serum were obtained and utilized. The criteria for inclusion included female blood donors aged 18 to 35 years old from the University of Brasília. The blood was collected at the Laboratory of Electron Microscopy, Institute of Biological Sciences, by the biomedical team, in accordance with all biosafety and storage best practices. For serum separation, the samples were coagulated and centrifuged afterwards.

\section{Synthesis and characterization of the samples}

The elaboration of the magnetic fluid samples based on maghemite NPs associated with rhodium (II) citrate dimer was conducted in a three-step procedure, as previously described, with some modifications $[7,25]$.

Synthesis of maghemite NPs: Magnetite NPs $\left(\mathrm{Fe}_{3} \mathrm{O}_{4}\right)$ were first obtained via alkaline co-precipitation of $\mathrm{Fe}^{2+}$ and $\mathrm{Fe}^{3+}$ ions and subsequently oxidized to maghemite $\left(\gamma-\mathrm{Fe}_{2} \mathrm{O}_{3}\right)$ [26]. Typically, 50.0 $\mathrm{mL}$ of an aqueous solution containing $50 \mathrm{mmol}$ of $\mathrm{FeCl}_{2} \cdot 4 \mathrm{H}_{2} \mathrm{O}$, $25 \mathrm{mmol}$ of $\mathrm{FeCl}_{3} \cdot 6 \mathrm{H}_{2} \mathrm{O}$ and $20 \mathrm{mmol}$ of $\mathrm{HCl}$ was rapidly poured into $250.0 \mathrm{~mL}$ of $1.0 \mathrm{~mol} / \mathrm{L} \mathrm{NH}_{4} \mathrm{OH}$ solution under stirring (1000 $\mathrm{rpm})$ at room temperature, for $30 \mathrm{~min}$. After this, the obtained precipitate $\left(\mathrm{Fe}_{3} \mathrm{O}_{4}\right)$ was magnetically separated and washed with water several times until the solution reached neutral $\mathrm{pH}$. The $\mathrm{pH}$ was then adjusted to about 4 with an $\mathrm{HCl}$ solution, and the produced $\mathrm{Fe}_{3} \mathrm{O}_{4}$ was oxidized to $\gamma-\mathrm{Fe}_{2} \mathrm{O}_{3}$ using an oxygen gas stream, at $80^{\circ} \mathrm{C}$ for $4 \mathrm{~h}$, under magnetic stirring. Thus, after washing the precipitate several times, NPs were resuspended in $\mathrm{HNO}_{3} 0.01$ $\mathrm{mol} / \mathrm{L}$. The concentration of $\gamma-\mathrm{Fe}_{2} \mathrm{O}_{3}$ in the solution $(1.9 \mathrm{~mol} / \mathrm{L})$ was obtained by determining the concentration of iron in solution by Inductively Coupled Plasma Optical Emission Spectrometry (ICP-OES).

Synthesis of the Rhodium (II) citrate dimer (RhCit): For the synthesis of Rhodium citrate dimer (RhCit), $0.78 \mathrm{mmol}$ of Rhodium (II) trifluoroacetate dimer was dissolved in $60.0 \mathrm{~mL}$ of water and the obtained solution was dropped into $5.0 \mathrm{~mL}$ of a solution containing $10.6 \mathrm{mmol}$ of citric acid previously heated to $70^{\circ} \mathrm{C}$. The heating was maintained until the volume of the solution was reduced to $\sim 1 \mathrm{~mL}$. Thus, $5 \mathrm{~mL}$ of water was added and the solution evaporated again. After repeating this step six times, the formed precipitate was dissolved in methanol and reprecipitated by the addition of a petroleum ether and acetone mixture 50:50 (v/v). The solid was then washed 20 times with ethyl acetate, to remove excess citric acid. Finally, after evaporating the excess ethyl acetate at $60^{\circ} \mathrm{C}$ for 12 hours, the solid was dissolved in $20 \mathrm{~mL}$ of $\mathrm{H}_{2} \mathrm{O}$. The concentration of RhCit was $0.058 \mathrm{~mol} / \mathrm{L}\left(\right.$ as $\left[\mathrm{Rh}_{2}\left(\mathrm{C}_{6} \mathrm{H}_{7} \mathrm{O}_{7}\right)_{4}\right]$ ), obtained by determining the concentration of rhodium by ICPOES measurements. 
Synthesis of magnetic NPs associated with RhCit (Mag-RhCit): As previously described [25], to synthesize the RhCit-coated $\gamma$ - $\mathrm{Fe}_{2} \mathrm{O}_{3}$ sample, an initial $\mathrm{RhCit} / \gamma$ - $\mathrm{Fe}_{2} \mathrm{O}_{3}$ molar ratio equal to 0.04 was used. Typically, $1.04 \mathrm{~mL}$ of RhCit solution and $0.79 \mathrm{~mL}$ of the $\gamma-\mathrm{Fe}_{2} \mathrm{O}_{3}$ magnetic fluid were mixed in $3.17 \mathrm{~mL}$ of water. After adjusting the $\mathrm{pH}$ to $\sim 3$ with $\mathrm{NaOH}$, the sample was moved to an overhead shaker with vertical rotation for $24 \mathrm{~h}(25 \mathrm{rpm})$. The sample was centrifuged for $10 \mathrm{~min}$ at $10,000 \mathrm{rpm}$ at $23^{\circ} \mathrm{C}$, the precipitate was washed three times with distilled water and NPs were redispersed in $10 \mathrm{~mL}$ of water at $\mathrm{pH} \sim 7$ (adjusted with $\mathrm{NaOH}$ ). The sample was named Mag-RhCit, with the iron and rhodium concentrations measured by ICP-OES equal to $290 \mathrm{mmol} / \mathrm{L}\left(145 \mathrm{mmol} / \mathrm{L}\right.$ in $\left.\gamma-\mathrm{Fe}_{2} \mathrm{O}_{3}\right)$ and $5.8 \mathrm{mmol} / \mathrm{L}\left(2.9 \mathrm{mmol} / \mathrm{L}\right.$ in $\left.\left[\mathrm{Rh}_{2}\left(\mathrm{C}_{6} \mathrm{H}_{7} \mathrm{O}_{7}\right)_{4}\right]\right)$, respectively.

Characterization of sample: In order to characterize the crystalline structure of the synthesized nanoparticles, X-ray diffraction (XRD) measurements, using a Rigaku-Miniflex 600 diffractometer, with a radiation of $1.541 \AA$ ( $40 \mathrm{kV}$ and $30 \mathrm{~mA})$, were carried out in the powdered samples obtained after evaporation of the solvent. The indexing of diffraction lines allowed the identification of the crystalline structure as well as the determination of the crystalline size and cell parameter. The hydrodynamic diameter (HD) and polydispersity index (PDI) were determined using Dynamic Laser Light Scattering (DLS) and the Zeta potential (ZP) of NPs was measured as the particle electrophoretic mobility by means of laser microelectrophoresis in a Zetasizer Nano ZS90, Malvern® apparatus. Prior to each reading, the as-prepared formulation was diluted $(1: 1000)$ with ultrapure water. The dilutions were not made in PBS because it has high ionic strength, causing agglomerations, as described in figures. For this reason, the tests involving the zetasizer were made with water. The temperature of analysis was maintained at $25^{\circ} \mathrm{C}$ and the scattered light intensity at $90^{\circ}$. The results were presented as the mean of triplicates, each replicate being composed of 10 measurements. The morphological characterization of the particles was performed by Transmission Electron Microscopy (TEM) in a JEOL JEM-2100, Thermo scientific, $200 \mathrm{kV}$ apparatus. For TEM analysis, diluted samples $(\sim 0.2 \mathrm{wt} \%)$ were dropped on copper grids previously coated with $0.7 \%$ Formvar and metallized with carbon. For analysis of the size distribution, 500 particles were counted from the images obtained by TEM.

For analysis of the composition of NPs associated to U-937 cells, distinct cell surface points were evaluated using the EDS system coupled with the Scanning Electron Microscope (JEOL JSM-700 $1 \mathrm{~F}$, JEOL, Japan) at $15 \mathrm{kV}$.

\section{Identification of the protein corona on Magh-RhCit}

Formation, desorption of the protein corona and preparation of the sample for identification: For formation of the protein corona, a $500 \mu \mathrm{L}$ suspension of magnetic fluid $(290.0 \mathrm{mmol} / \mathrm{L} \mathrm{Fe})$ was ultrasonically dispersed (Branson 1510 B-series ultrasonic cleaners) for 10 minutes, at 60 Hertz. It was then incubated for 1 hour at $37^{\circ} \mathrm{C}$ in a $1.5 \mathrm{~mL}$ test tube containing $500 \mu \mathrm{L}$ of human blood serum. The same protocol was done for the negative controls, but without the addition of serum to the NPs (NP+PBS; NP+Simple RPMI Medium).

Following incubation, non-binding proteins were eliminated. The tubes were centrifuged at $16,000 \mathrm{~g}$ for 1 hour at $4^{\circ} \mathrm{C}$ (EppendorfCentrifuge 5424 R, with Rotor FA-45-24-11) and the supernatant was separated from sediment. The supernatant was replaced with the same amount of PBS and the procedure was repeated four times.
After the last washing step, the pellets were resuspended in $200 \mu \mathrm{l}$ of $1 \mathrm{X}$ buffer (0.0625 M Tris-HCL, 2.5\% SDS, 5\% 2-Mercaptoethanol, $7 \%$ Glycerol) and frozen to $-20^{\circ} \mathrm{C}$. The supernatants of the NP sample with human serum were concentrated in a speed vac to a volume of $100 \mu \mathrm{L}$ and analyzed by SDS-PAGE (sodium dodecylsulfate polyacrylamide gel electrophoresis) for their protein content to determine the effectiveness of the washing.

For desorption of surface proteins from NPs, the samples were heated at $95^{\circ} \mathrm{C}$ for 10 minutes in an incubator (AccuTherm ${ }^{\mathrm{TM}}$ Microtube Shaking Incubator/Labnet). Samples were precipitated by centrifugation at $16,000 \mathrm{~g}$ at $25^{\circ} \mathrm{C}$ for 30 minutes. Protein supernatant was collected and $2 \mu \mathrm{L}$ were used for quantification of protein content. The quantification was performed using a Qubit ${ }^{\circledR}$ 2.0 Fluorometer quantification kit from Invitrogen.

To verify the presence of proteins, analysis was performed by SDSPAGE. To denature the proteins, the samples were boiled for 10 minutes at $95^{\circ} \mathrm{C}$ in a water bath, added to $1 / 5$ sample buffer and applied on $5-12 \%$ bis-polyacrylamide gel. Electrophoresis was done with run buffer in a $120 \mathrm{~V}$ Bio-Rad kit for 1 hour to separate the proteins by molecular weight. A volume of $15 \mu \mathrm{l}$ of sample marker was used. The gel was stained using 1\% coomassie blue (BIO-RAD) for 1 hour and decolorized with a solution of $50 \mathrm{~mL}$ of distilled water, $40 \mathrm{~mL}$ of methanol and $10 \mathrm{~mL}$ of acetic acid.

The sample containing protein extracts was submitted to tryptic digestion using the sample digestion protocol of Promega (2001) with some adaptations. The sample was resuspended in $100 \mu \mathrm{L}$ of Guanidine buffer (6 M+Tris $0.25 \mathrm{M}, \mathrm{pH} 8.6+10 \mathrm{mM}$ DTT) and reduced for $1 \mathrm{~h}$ at $56^{\circ} \mathrm{C}$ under $\mathrm{N}_{2}$ to avoid oxidation. The sample was then alkylated with Iodoacetamide $(55 \mathrm{mM})$ for $45 \mathrm{~min}$ at $25^{\circ} \mathrm{C}$.

To remove the SDS, 2-Mercaptoethanol, DTT, IAA and Guanidine present in the sample, Amicon filter was used with a cut-off of $30 \mathrm{kDa}$. After ultrafiltration the sample was lyophilized and resuspended in $100 \mu \mathrm{L}$ of $0.1 \mathrm{Mol} / \mathrm{L}$ ammonium bicarbonate buffer, $\mathrm{pH} 8.1$ with $2 \% \mathrm{w} / \mathrm{w}$ Promega trypsin and digested at $37^{\circ} \mathrm{C}$ for 20 hours overnight.

Then the digested sample was cleaned up in StageTips and a small aliquot was analyzed by MALDI (Bruker Autoflex II MALDI-TOF/ TOF), for quality control, followed by LC-MS/MS Orbitrap analysis (LTQ Velos Pro Orbitrap Elite).

Liquid Chromatography Coupled to Mass Spectrometry (LCMS/MS): The tryptic peptide samples were analyzed by a capillary column chromatographic system (Dionex Ultimante 3000 nanoUHPLC) coupled online to the Orbitrap Elite ${ }^{\mathrm{TM}}$ ion trap-orbitrap hybrid mass spectrometer (Thermo Scientific, Bremen, Germany). The solvents used in the tests were: solvent $\mathrm{A}(0.1 \%$ formic acid in water) and solvent B ( $0.1 \%$ formic acid in acetonitrile).

The chromatographic system consists of two types of capillary columns, a pre-column (internal diameter of $100 \mu \mathrm{m} \times 2 \mathrm{~cm}$ in length), packed with $5 \mu \mathrm{m}$ C18 ReprosilPur-coated silica spherical particles with $120 \AA$ pores (Dr. Maich GmbH, Ammerbuch, Germany). Samples that were injected and loaded into this precolumn were carried out at a flow rate of $3 \mu \mathrm{L} / \mathrm{min}$ of solution, of which $98 \%$ was solvent $\mathrm{A}$ and $2 \%$ solvent $\mathrm{B}$. The second column is an analytical column (internal diameter of $75 \mu \mathrm{m} \times 35 \mathrm{~cm}$ in length) packed with $3 \mu \mathrm{m}$ Reprosil C18 particles with $120 \AA$ pores (Dr. Maich GmbH, Ammerbuch, Germany). The peptides were 
separated in this analytical column and eluted using gradients of 2 to $40 \%$ solvent $\mathrm{B}$ in $170 \mathrm{~min}$.

The compounds eluted from the analytical column directly into the mass spectrometer ionization chamber. The source of ionization used was Nanospray flex ion source (Thermo Scientific,), with the spray voltage set to $2.5 \mathrm{kV}$ and a transfer capillary temperature of $275^{\circ} \mathrm{C}$. MS spectra were acquired in positive mode, with data dependent acquisition (DDA). The DDA cycle consisted of a survey scan comprising the range $\mathrm{m} / \mathrm{z}$ 300-1650 under the resolution of 120,000 FWHM (Full Width at Half-Maximum) for $\mathrm{m} / \mathrm{z} 400$ and with target value of automatic gain control of $1 \times 10^{6}$ ions for all scans in the FTMS and maximum fill time of $200 \mathrm{~ms}$. The survey scan was followed by collision induced dissociation (CID) MS/MS fragmentation of the 15 most abundant multi-charged precursor ions at each time interval. The isolation window for the selection of the monoisotopic precursor ion was $2 \mathrm{Th}$. Previously fragmented precursor ions were dynamically excluded for $90 \mathrm{~s}$.

Identification of protein: The raw files from all chromatographic runs were submitted to data processing and analysis in the PEAKS Studio 7.0 program (Bioinformatics Solutions Inc., Waterloo, ON, Canada). The following parameters were used for analysis: trypsin as enzyme; tolerance for mass error of $10 \mathrm{ppm}$ monoisotope precursor; mass error for 0.5 Da fragments; maximum of two missed cleavages; carbamidomethylation of cysteine residues (alkylation with iodoacetamide) as a fixed modification; acetylation of the $\mathrm{N}$-terminal of the protein and oxidation of methionine as variable modifications; maximum of three post-translational modifications per peptide.

The data were confronted with the database of Homo sapiens (161,549 sequences, downloaded from Uniprot on January 5, 2018). A false positive detection rate (FDR) was estimated by merging the database with a decoy bank. A reliable identification was considered for proteins presenting FDR $<1 \%$ and at least one unique peptide.

\section{Assays with the U-937 cell line}

Cell culture: The human leukemic monocyte lymphoma cell line, U-937, was purchased from the American Type Culture Collection (ATCC ${ }^{\natural}$ CRL-1593.2). Cells were cultured in RPMI-1640 medium, supplemented with $10 \%$ fetal bovine serum (SFB) and $1 \%$ antibiotic $(100 \mu \mathrm{g} / \mathrm{mL}$ penicillin and $100 \mu \mathrm{g} / \mathrm{mL}$ streptomycin), incubated at $37^{\circ} \mathrm{C}, 5 \% \mathrm{CO}_{2}$, and humidity of $80 \%$.

Induction of in vitro differentiation of human macrophages: In order to induce cell differentiation of the U-937 lineage to a macrophage phenotype, the cells were seeded $\left(4 \times 10^{5}\right)$ on a 6-well polystyrene (TPP, USA) plate and incubated with medium culture (RPMI) (GIBCO, USA) supplemented with $5 \mathrm{ng} / \mathrm{mL}$ phorbol 12-myristate 13-acetate (PMA) (Sigma-Aldrich, USA). This concentration was established in previous work $[7,14,16]$, for 48 hours and 72 hours to establish the best differentiation time. A well with control cells did not receive PMA. Subsequently, the cells were washed with phosphate buffered saline (PBS) composed of $137 \mathrm{mM} \mathrm{NaCl}, 2.7 \mathrm{mM} \mathrm{KCl}, 10 \mathrm{mM} \mathrm{Na} 2 \mathrm{HPO}$ 4; $2 \mathrm{mM} \mathrm{KH}_{2} \mathrm{PO}_{4}$ at $\mathrm{pH} 7.4$ and incubated for 24 hours in RPMI-1640 without PMA. The experimental study was done duplicated, and an Axiovert light microscope was used to analyze the cell morphology using AxioVision 100 software for image capture (both from Zeiss, Germany).
Flow cytometry: Following the induction of human macrophage differentiation after 24 hours of incubation in RPMI-1640 without PMA, the medium was removed and the cells washed 3 times with PBS. They were then removed from the plate by 2 methods: cell scraper, $25 \mathrm{~cm}, \mathrm{KASVI}$ ) and trypsin. The intent was to evaluate the effects of trypsin on CD-14 marker receptors. Separated cells were incubated for 30 minutes with APC-Alexa fluorine 750 (Invitrogen/ Life/Thermo) conjugated anti-human CD14 on ice. After three washes with centrifuging PBS, the cells were resuspended in 400 $\mu \mathrm{l}$ of PBS and analyzed on the flow cytometer (FACS Calibur, BD Biosciences, Inc., San Jose, CA). Data analysis was performed in the Flow Jo v.5.2.7 program, Tree Star, Inc.

Treatment of macrophages of the U-937 lineage with Magh-RhCit NPs coated by CP for morphological analysis, quantification of internalized iron and rhodium content and cell viability: Initially, the Magh-RhCit NPs were incubated with human blood serum for 1 hour at $37^{\circ} \mathrm{C}$. Next, the samples were washed 4 times with PBS by centrifugation to release the unbound, dispersed and diluted components in RPMI medium without FBS for the subsequent treatment of the cells.

Morphological analysis by Scanning Electron Microscopy and Transmission Electron Microscopy: Differentiated U-937 cells were plated at $1 \times 10^{6}$ cells in a 6-well plate (with a specific coverslip) and after adhesion were incubated with CP nests at 200 $\mu \mathrm{M}$ rhodium citrate $[2.9 \mathrm{mmol} / \mathrm{L}]$ for 1,3 and 6 hours. The well with cells without treatment was used as control.

For SEM analysis, the cells were fixed with Karnovsky (2\% glutaraldehyde, 2\% paraformaldehyde, 3\% sucrose, $0.005 \mathrm{M}$ calcium chloride in $0.1 \mathrm{M}$ sodium cacodylate buffer, $\mathrm{pH}$ 7.2) overnight at $4^{\circ} \mathrm{C}$. Subsequently, the cells were washed with $0.1 \mathrm{M}$ sodium cacodylate buffer ( $\mathrm{pH} 7.2$ ) and post-fixed for 30 minutes with $1 \%$ osmium tetroxide. Cells were washed twice with distilled water and dehydrated on a gradient of acetone $(50 \%-100 \%)$ for 5 minutes each. After dehydration, the samples were dried in Critical Point (Balzers CPD 030), mounted on a specimen port and metalized with Gold $(\mathrm{Au})$ in the "Sputter Coater" (Leica, EM SCD 500). The samples were analyzed in the Scanning Electron Microscope (Jeol, JGM 7001F, Tokyo, Japan).

For TEM analysis, the trypsin-depleted cells were collected in microtubes and washed with PBS. They were then fixed with Karnovsky (2\% glutaraldehyde, 2\% paraformaldehyde, 3\% sucrose, $0.005 \mathrm{M}$ calcium chloride in $0.1 \mathrm{M}$ sodium cacodylate buffer, $\mathrm{pH}$ 7.2) overnight at $4^{\circ} \mathrm{C}$. Subsequently, cells were washed with $0.1 \mathrm{M}$ sodium cacodylate buffer ( $\mathrm{pH} 7.2$ ) and post-fixed for 30 minutes with $1 \%$ osmium tetroxide and $0.8 \%$ potassium ferricyanide in sodium cacodylate buffer and $5 \mathrm{mM} \mathrm{CaCl}_{2}$. The cells were washed twice with distilled water and then contrasted in block with $0.5 \%$ uranyl acetate at $4^{\circ} \mathrm{C}$. The samples were dehydrated in an increasing gradient of acetone $(30 \%-100 \%)$ for 10 min each and included in Spurr resin. The ultrafine sections were obtained with an ultramicrotome (Leica, UCT, AG, Vienna, Austria) and analyzed in a Transmission Electron Microscope (Jeol 1011, Tokyo, Japan).

Quantification of iron and rhodium in cells by ICP-OES: To determine the content of $\mathrm{Fe}$ and $\mathrm{Rh}$ in cells of cell line U-937, the differentiated cells were seeded $\left(1 \times 10^{5}\right)$ in 24-well polystyrene plates and treated with protein corona in Magh-RhCit at $200 \mu \mathrm{M}$ rhodium citrate $[2.9 \mathrm{mmol} / \mathrm{L}]$. After the incubation time $(6,12,24$, 48 and 72 hours), the cells were collected in $1.5 \mathrm{~mL}$ microtubes and 
washed 5 times with PBS using a centrifuge $\left(5000 \mathrm{rpm} / 37^{\circ} \mathrm{C} / 10\right.$ $\mathrm{min})$. The supernatants were collected in $15 \mathrm{~mL}$ conical tubes for quantification of the non-internalized metal. Cells were dried in speed vac, resuspended in $200 \mu \mathrm{L}$ of $\mathrm{HNO}_{3}$ and then transferred to a $15 \mathrm{~mL}$ conical tube for ageing for 24 hours. Samples were diluted with water to $5 \mathrm{~mL}$ and analyzed by ICP-OES. The same protocol was used for supernatants.

Cell viability by the MTT method: Cell viability was evaluated by the colorimetric method of 3 (4,5-dimethylthiazol-2-yl) -2,5-diphenyl-tetrazolium bromide (MTT). The differentiated cells were seeded in a 96-well plate $\left(4 \times 10^{3}\right.$ per well) and incubated with RPMI medium for 24 hours in a humidified greenhouse containing $5 \% \mathrm{CO}_{2}$ at $37^{\circ} \mathrm{C}$. After 24 hours, they were incubated with NPs with CP for various periods (24, 48 and 72 hours) in the concentrations of $50,100,200$ and $300 \mu \mathrm{M}$ of rhodium citrate [2.9 mmol/L]. After the treatment incubation period, the contents of the wells were replaced with a solution of medium containing $0.5 \mathrm{mg} / \mathrm{mL}$ MTT $(5 \mathrm{mg} / \mathrm{mL}$ in $0.15 \mathrm{M} \mathrm{PBS})$ for 2.5 hours in a humidified greenhouse containing $5 \% \mathrm{CO}_{2}$ at $37^{\circ} \mathrm{C}$ and then 200 $\mu \mathrm{L}$ dimethylsulfoxide (DMSO) was added. DMSO blank and cellfree treatment were performed. The analysis of formazan crystals was quantified in a spectrophotometer (SpectraMax M2, Molecular Devices) using wavelength of $595 \mathrm{~nm}$.

\section{Statistical analysis}

Statistical analysis was performed using GraphPad Prim software. All graph values are plotted as means \pm SEM. Two-way ANOVA analysis was performed (Dunnett's multiple comparisons test). Significant differences were considered when the probability was less than $5 \%(\mathrm{p}<0.05)$.

\section{RESULTS AND DISCUSSION}

Characterization of magnetic fluid Magh-RhCit and physical-chemical changes following incubation with human blood serum

The association of rhodium citrate dimer ( $\mathrm{RhCit}$ ) with maghemite NPs $\left(\gamma-\mathrm{Fe}_{2} \mathrm{O}_{3}\right)$, as described in the experimental section, allowed a concentrate $(\sim 23 \mathrm{mg}$ of solid per $\mathrm{mL})$ and a very stable aqueous solution to be obtained over a long period of time. In fact, no sedimentation nor important $\mathrm{pH}$ variation $(\mathrm{pH}=6.8 \pm 0.2)$ were observed during the 24 months of evaluation of the synthesized Mag-RhCit sample. Besides, the colloidal parameters of a two-year- old sample, HD $147 \mathrm{~nm}, \mathrm{ZP} \sim-40 \mathrm{mV}$ and PDI $~ 0.17$, indicates a condition of high colloidal stability, corroborating visual observations $[26,27]$. However, the stability was also monitored by means of these colloidal parameters over a long period of time, as shown in Figure 1. During this period, the hydrodynamic diameter (HD) slightly decreased but ranged between $145 \mathrm{~nm}$ and $150 \mathrm{~nm}$, while the polydispersity index (PDI) variation was very slight (always $<0.2$ ); the zeta potential (ZP) also varied but remained $\sim 35 \mathrm{mV}$ at the end of the period of observation. Moreover, this negative value of $\mathrm{ZP}$ strongly indicated the success of the surface coating with $\mathrm{RhCit}$ molecules, since bare $\gamma-\mathrm{Fe}_{2} \mathrm{O}_{3} \mathrm{NPs}$ are expected to present ZP close to zero at $\mathrm{pH} \sim 7$. Otherwise, after the adsorption of ligands, the complexation of NPs' surface by carboxylic moieties of RhCit took place. Besides, some - $\mathrm{COOH}$ moieties remained solution-oriented, as free ionizable groups, providing the negative superficial charge and increasing the colloidal stability of Mag-RhCit NPs through electrostatic interparticle repulsion [7,23,24].

In this study, Magh-RhCit NPs had stable $\mathrm{pH}$ even after 2 years of synthesis $(\mathrm{pH}=6.8)$. The mean HD was $147.4 \pm 1.380$, and the surface $\mathrm{ZP}, \mathrm{P} \zeta-40.1 \mathrm{mV}$, and monodisperse characteristics with the PDI of $0.171 \pm 0.006$ (Figure 1).

Figure 2A shows a micrograph of sample Mag-RhCit obtained by Transmission Electron Microscopy (TEM). It was observed that NPs are spherical and have polydispersity of a size expected for syntheses by co-precipitation route and as also observed by other authors. [7,21-24,28]. The analysis of the histogram of Figure 2B,

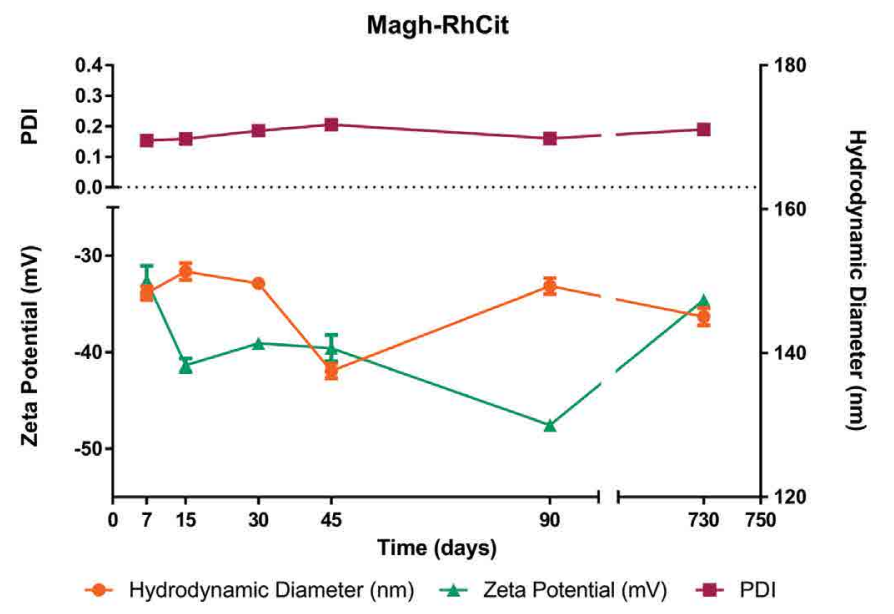

Figure 1: Colloidal stability analysis of Mag-RhCit sample over time (7, 15, $30,45,90$ and 730 days).
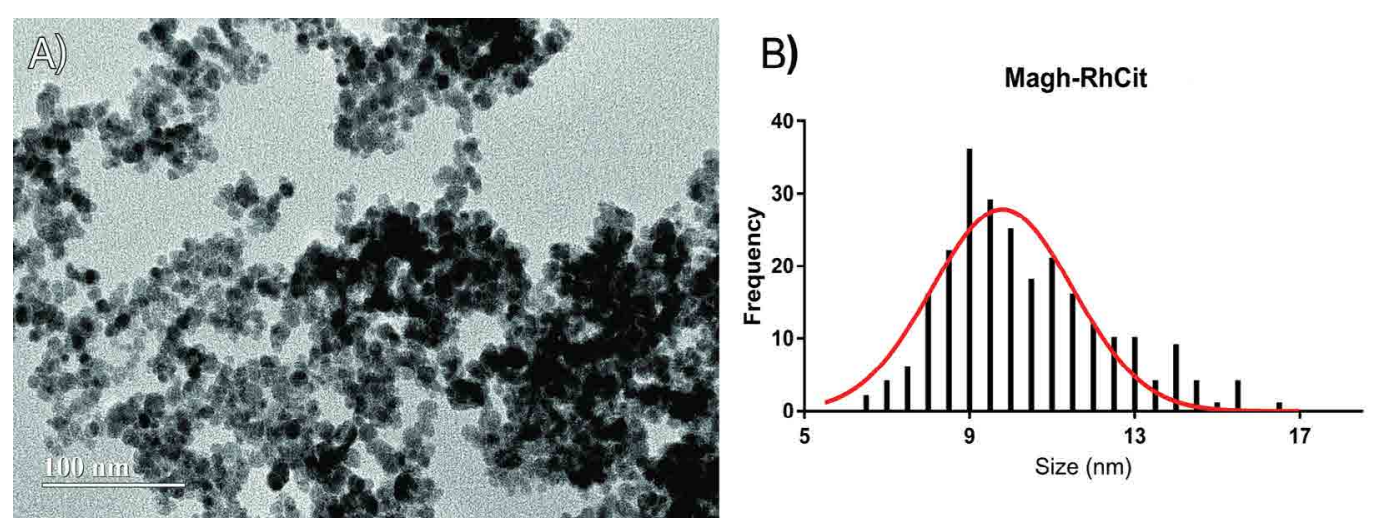

Figure 2: A) Electron micrograph of magnetite nanoparticles associated with rhodium citrate Mag-RhCit. B) Histogram of Magh-RhCit diameter distribution. Mean: $9.65 \mathrm{~nm} \pm 1.707$; Mode: $9.4 \mathrm{~nm}$. 
obtained from the analysis of TEM pictures of the Mag-RhCit sample, showed a mean size of $9.65 \mathrm{~nm}$, mode $9.4 \mathrm{~nm}$.

Figure 3 shows the X-ray diffraction pattern of the Mag-RhCit sample. All diffracted peaks were indexed to a face-centered cubic spinel structure $(\mathrm{Fd} 3 \mathrm{~m})$ of maghemite, and the calculated lattice parameter (0.836) showed good correlation with the expected value $(0.83515 \mathrm{~nm})$, obtained from the literature (JCPDS \#39. 1346). Moreover, using the Scherrer equation, through the full width at half-maximum of the most intense (311) diffraction peak, a mean crystalline diameter of $d_{R X}=9.75 \mathrm{~nm}$ was obtained, which corroborated the results of the TEM.

The colloidal stability of the Mag-RhCit sample was tested with NPs dispersed in different media. Figure 4A and 4B respectively show that samples diluted in PBS and pure RPMI culture medium precipitate after dilution. However, when dispersed in RPMI culture medium supplemented with human blood serum (Figure 4C), colloidal stability is preserved as in the sample diluted in pure water (Figure 4D). The phase separation observed in Figure $4 \mathrm{~A}$ and $4 \mathrm{~B}$ can be associated with the high ionic strength of PBS buffer and RPMI medium, which screen double-layer forces and induce particle aggregation [29]. Otherwise, the formation of a PC in RPMI culture medium supplemented with human blood serum is likely to be responsible for the increased colloidal stability of the NPs by an electrosteric hindrance contribution of adsorbed proteins, even at high ionic strength [30].

To evaluate the effect of PC on the colloidal stability of NPs, the HD, PDI and ZP parameters were measured for samples incubated in pure water or in diluted human blood serum (for 0,12 , and 24 h) at $25^{\circ} \mathrm{C}$ and $37^{\circ} \mathrm{C}$. Figure $5 \mathrm{~A}$ shows that the $\mathrm{ZP}$ of NPs dispersed in water (approximately $-43 \mathrm{mV}$ ) decreases - in modulus - to

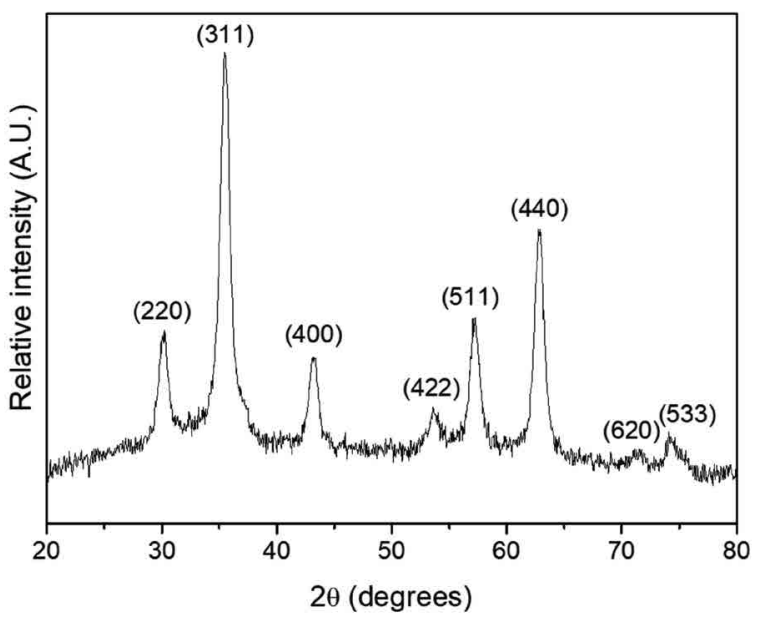

Figure 3: X-ray diffraction pattern of sample Mag-RhCit. The interplanar distances and the relative intensity of the diffraction peaks were compared with the American Society for Testing Materials (ASTM) database for maghemite.

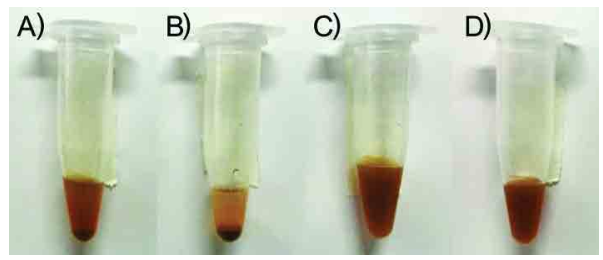

Figure 4: Images of Mag-RhCit sample diluted (10 times) in different media. A) PBS; B) RPMI medium; C) RPMI medium + human blood serum and $\mathrm{D}$ ) water.
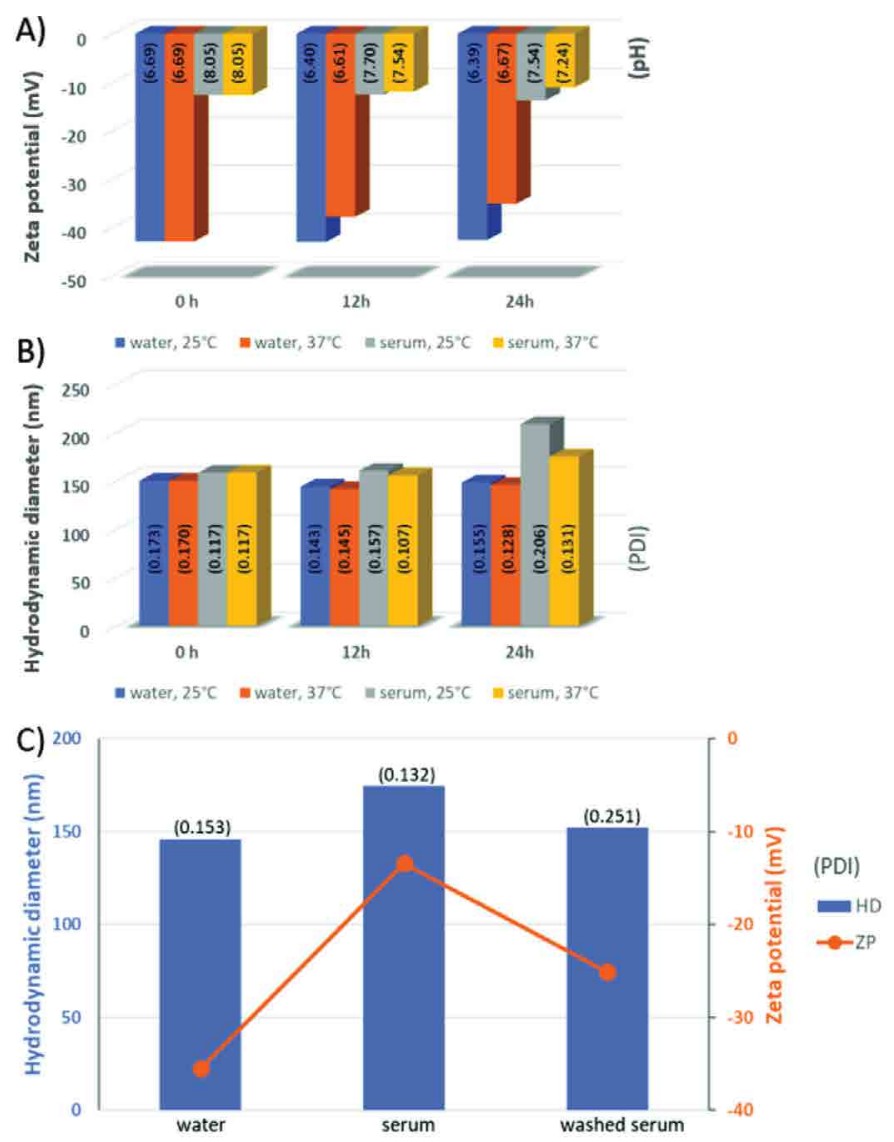

Figure 5: A) ZP and $\mathrm{pH}$ (between parenthesis) and $\mathrm{B}$ ) HD and PDI (between parenthesis) of samples containing NPs incubated in water or serum at different temperatures; C) ZP, HD and PDI (in parenthesis) of samples containing NPs incubated in water, in serum and those incubated in serum, but washed 4 times and redispersed in water.

about $-13 \mathrm{mV}$, after the interaction with serum and formation of PC. The predominance of negative ionizable carboxyl groups on rhodium citrate-functionalized NPs, when compared to the positive and negative moieties on the PC capping, might be responsible for the decrease of the superficial charge of NPs in the presence of serum [30]. Moreover, the ZP slightly decreases, mainly for NPs dispersed in water, for samples incubated at $37^{\circ} \mathrm{C}$, probably due to the partial desorption of surface coating. The $\mathrm{pH}$ (see values in parentheses in Figure 5A also increases after the formation of $\mathrm{PC}$, but does not vary importantly over the incubation time. It is worth noting that at $\mathrm{pH} 7$ the negative moieties present in $\mathrm{RhCit}$ and $\mathrm{PC}$ are (i.e. - $\mathrm{COO}$ ) preferably ionized when compared to the positive groups (i.e. $-\mathrm{NH}_{3}^{+}$) present only in PC. The HD of NPs dispersed in serum increased as the time of incubation increased from $0 \mathrm{~h}$ to $24 \mathrm{~h}$ (Figure 5B). This behavior, not observed in NPs dispersed in water, was more evident in samples incubated at $25^{\circ} \mathrm{C}$. As the PDI followed the same tendency, this increase in HD might be associated with the formation of agglomerates, corroborating the decrease in $\mathrm{ZP}$ verified in Figure 5A.

Figure 5C shows the ZP, HD and PDI data of samples containing NPs incubated in water, in serum and those incubated in serum, but washed 4 times, separated by centrifugation, and redispersed in water. The ZP decreases after washing but still remains higher than that of the serum-free sample, indicating that proteins remain firmly attached to the surface of NPs even after the washing 
process. Besides, the HD and PDI results also corroborate the gain of colloidal stability originating from PC on the surface of NPs.

\section{Identification and characterization of the protein corona of the Magh-RhCit NPs}

The samples were washed four times with a buffer to remove unbound proteins from the protein corona (Figure 6A). After PC desorption, $2 \mu$ of the supernatant was used to quantify the protein content. The sample had $66 \mu \mathrm{g} / \mu \mathrm{L}$ of protein. The confirmation that blood serum proteins adsorbed on the surface of the NPs can be seen in Figure 6B.

Protein identifications were performed by using liquid chromatography coupled to mass spectrometry (LC-MS/MS), and 83 proteins with a false discovery rate (FDR) of less than $1 \%$ were identified. The identified proteins were further classified and grouped for GO terms, interactions and pathways using the software BLAST2GO, STRING public databases, and, additionally, the BLASTKOALA system of automatic annotation. Then a total of 49 proteins were characterized (Table 1). Among them, 1 was albumin (ALB), 1 complement protein (C5), 3 kinases (AKAP 13), 5 apolipoproteins (APOA1), 4 glycoproteins, 5 haptoglobins (HP), 4 transferrins (TF), 2 Alpha-1 antitrypsin (SERPINAS1) and 24 immunoglobulins (IgGs).

Albumin is the most commonly found protein in the PC of various nanomaterials [31-35], and the most abundant in the serum $(55 \%)$ [36,37]. However, low-abundance proteins, such as immunoglobulins, apolipoproteins and fibrinogen, are also found in the corona $[31,33,38]$, and in some cases, in greater concentrations than albumin, as observed in the protein corona of Magh-RhCit.

Proteins such as albumin, immunoglobulins, complement proteins, fibrinogen, apolipoproteins and transferrin tend to bind more strongly to nanomaterials and have been shown to promote opsonization, phagocytosis, and endocytosis $[39,40]$. The majority

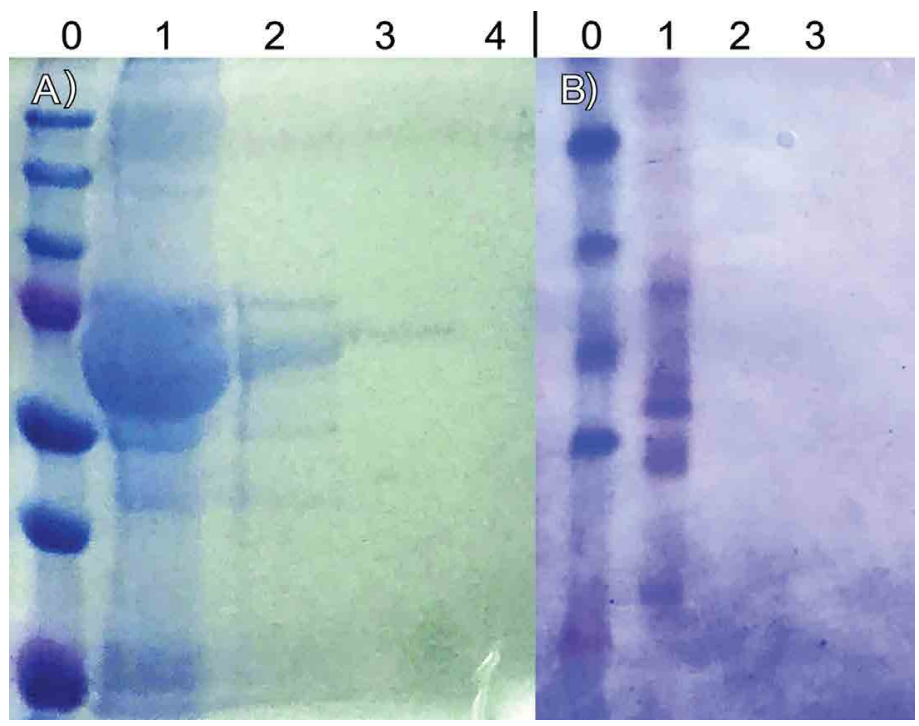

Figure 6: A) Acrylamide gel showing the electrophoretic profile of the supernatant from NP washing steps after incubation with serum. 0 marker; 1, 2, 3 and 4 were the successive washes performed on the MaghRhCit sample incubated with human blood serum. B) Electrophoretic profile of proteins removed from NP surface. 0: marker; 1 : NP + human blood serum; 2: NP + PBS; 3: NP + RPMI medium (without SFB). of these proteins are able to adhere to ionic and metallic surfaces. This explains the presence of some of them on the surface of the Magh-RhCit.

In addition to the above-mentioned proteins, kinase and Alpha-1 antitrypsin were also identified. Kinase (AKAP13) catalyzes the phosphorylation of proteins by transferring an ATP or GTP phosphate group [41]. Zhu, et al. [42] studied the structure of the hydroxyapatite magnetic protein corona and showed that it enhances cell proliferation due to activation of mitogen protein kinase signaling.

Alpha-1 antitrypsin belongs to the family of serpins produced in the liver. Its main physiological function is to inhibit elastase released by leukocytes, an enzyme that digests damaged or aging cells and bacteria; therefore, its inhibitor promotes healing, in addition to being a trypsin inhibitor [43]. It is found on the surface of several nanomaterials, mainly the PEGylated [44-46], solid lipid [47] and polymerics [45,48-50]. Goppert \& Müller [47] have shown that alpha-1 antitrypsin increases the concentration of the NP on the surface during incubation time and can be explained using the "Vroman effect", in which less abundant proteins replace more abundant ones because they have greater affinity with the surface of the nanomaterial [51].

PC affects the fate of NPs in a biological environment, and is described as crucial to an application of nanotechnology. A protein corona identified in this work contributes to the characterization and biological study of the Magh-RhCit NP. Most associated proteins promote opsonization, and this is one of the barriers found in the course of the tumor. On the other hand, they may reach the tumor but may be included by M2-type macrophages, which may destabilize it. However, studies need to be done to get more information on the subject. Next, we will show some results obtained from the interaction of Magh-RhCit with PC in macrophages derived from the U-937 lineage.

\section{Evaluation of the influence of the protein corona during Magh-RhCit internalization with human macrophages, and cell viability}

Differentiation of the human monocytic cell line, U-937, into macrophage-like cells using phorbol myristate acetate (PMA) (5 $\mathrm{ng} / \mathrm{mL}$ ) during a 72 hour incubation period was considered more satisfactory then when compared to periods shorter than 48 hours (Figures 7 and 8), and corroborates previous studies performed with THP-1 monocytic lineages [14] and U-937 [18].

To ensure that exposure time at this concentration $(5 \mathrm{ng} /$ $\mathrm{mL} \mid 72$ hours) is sufficient for cell differentiation, the levels of CD14 expression were analyzed. By observing the adherent cell morphology (Figure 7C), and the CD14 labeling analysis using flow cytometry, it was noted that the time of 72 hours induces 53.4\% differentiation (CD14+) (Figure 8).

Through Scanning and Transmission Electron Microscopy, analysis of the U-937 cell line, it was possible to visualize the interaction of the NPs with the cells. From observing NPs on the surface of the membrane, we identified morphological changes over the course of hours, as well as decreased prolongations in the control cell (Figures 9A-9A3) and vesicle formation with increased internalization (Figure 9B-B3). After 1 hour of treatment (Figure 9B1), the cells already have agglomerates of internalized NPs in vesicles (indicated 
Table 1: Description of the proteins identified on the surface of Magh-RhCit.

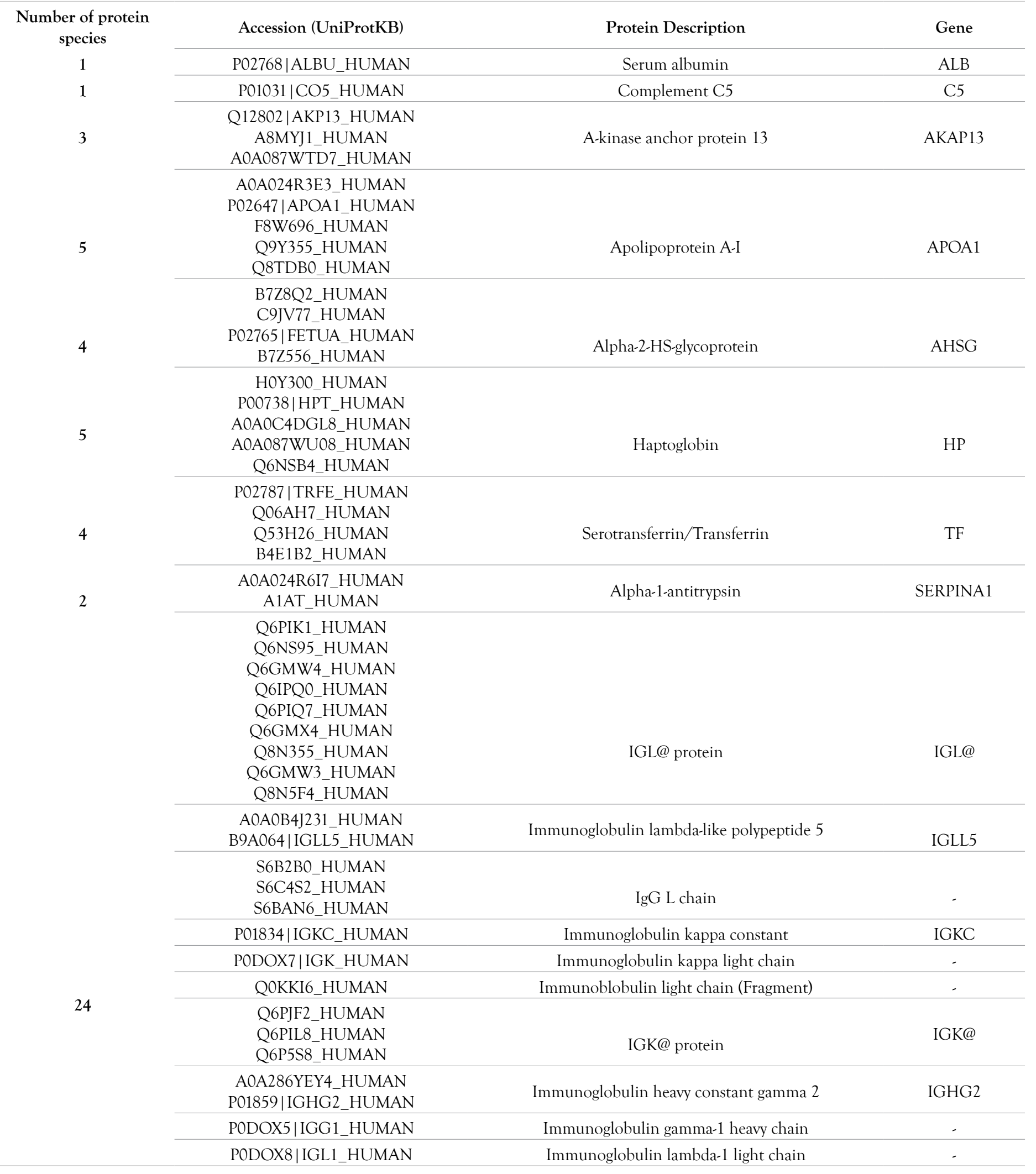

by red arrows). Over time, the number of vesicles increases (Figure 9B1 and 9B2).

Energy Dispersive Spectroscopy (EDS) analysis provided the chemical composition of NP associated with U-937 cells, with an average of $3.2 \%$ of iron and $1.7 \%$ of rhodium (Figure 10 ). Therefore, it is possible to state that the material on the cell surface is in fact NPs.
An inductively coupled plasma optical emission spectrometry (ICP-OES) method used to quantify NPs inside the cells revealed the concentration of approximately $9.17 \mu \mathrm{mol} / \mathrm{L}$ of iron and 0.09 $\mu \mathrm{mol} / \mathrm{L}$ of rhodium in the first few hours of treatment. During the 48-hour period, concentration increased to $47.7 \mu \mathrm{mol} / \mathrm{L}$ and $0.49 \mu \mathrm{mol} / \mathrm{L}$, respectively (Figure 11A). In accordance with the capture of NPs from the supernatant, the amounts of NP in the supernatant decreased, with two remarkable drops over the 72-hour 


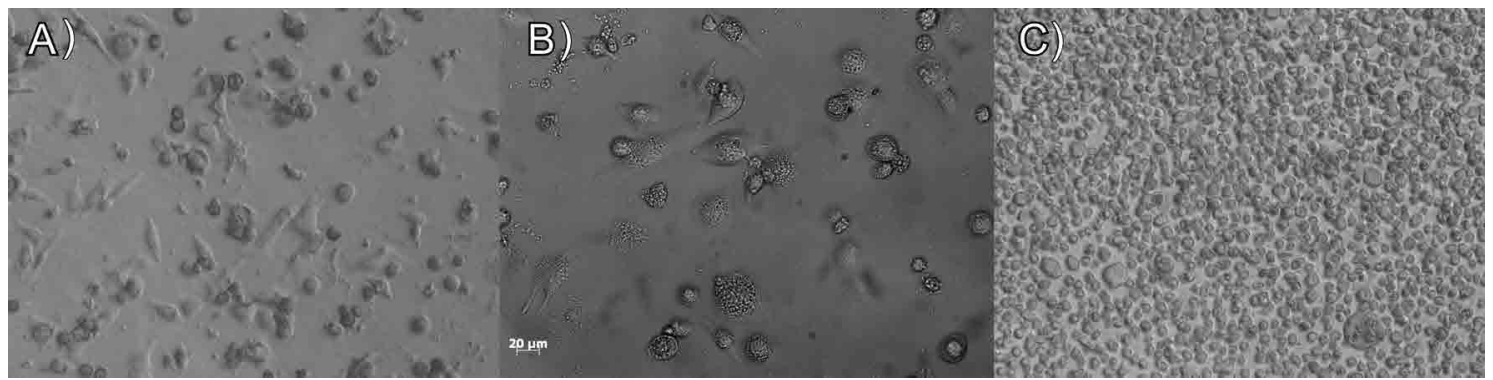

Figure 7: Micrographs of U-937 cells differentiation. A) Monocytes suspension cultures showing spherical shape (control); B) After 48 hours of PMA exposure, some cells become adhered and larger, indicating cell differentiation; C) After 72 hours of PMA exposure, a larger number of cells become adhered and larger
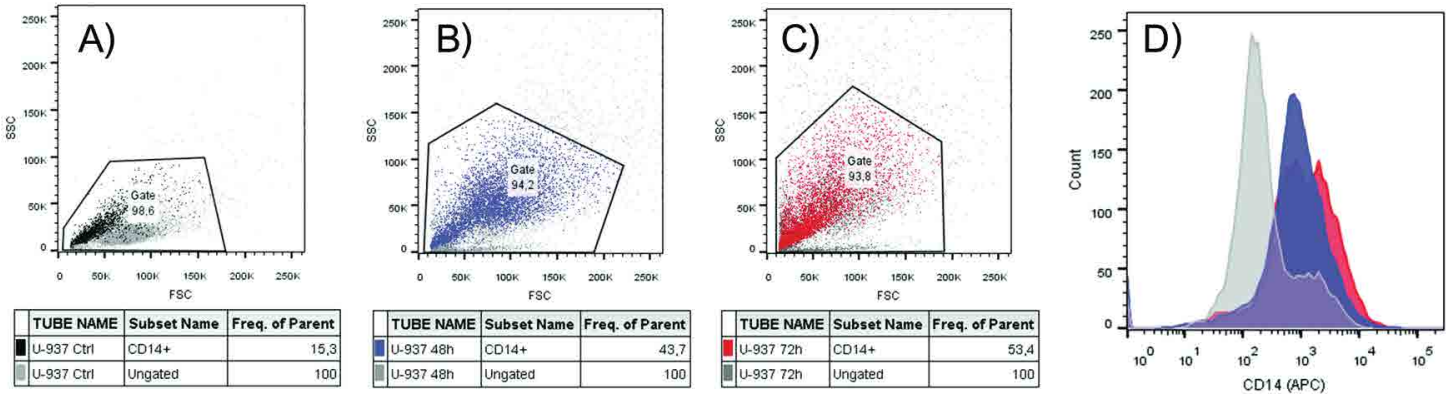

Figure 8: Flow cytometry analysis of the percentage of PMA differentiation of the U-937 lineage of macrophages CD14 ${ }^{+}$and monocytes. A) Control monocytes without PMA incubation in black. B) CD14+ cell populations after PMA incubation for 48 hours in blue. C) and CD14+ cell populations after PMA incubation for 72 hours in red. D) Count of cells presenting CD14 as surface marker. In gray is the control population, in blue the population with incubation period of 48 hours and red of 72 hours.

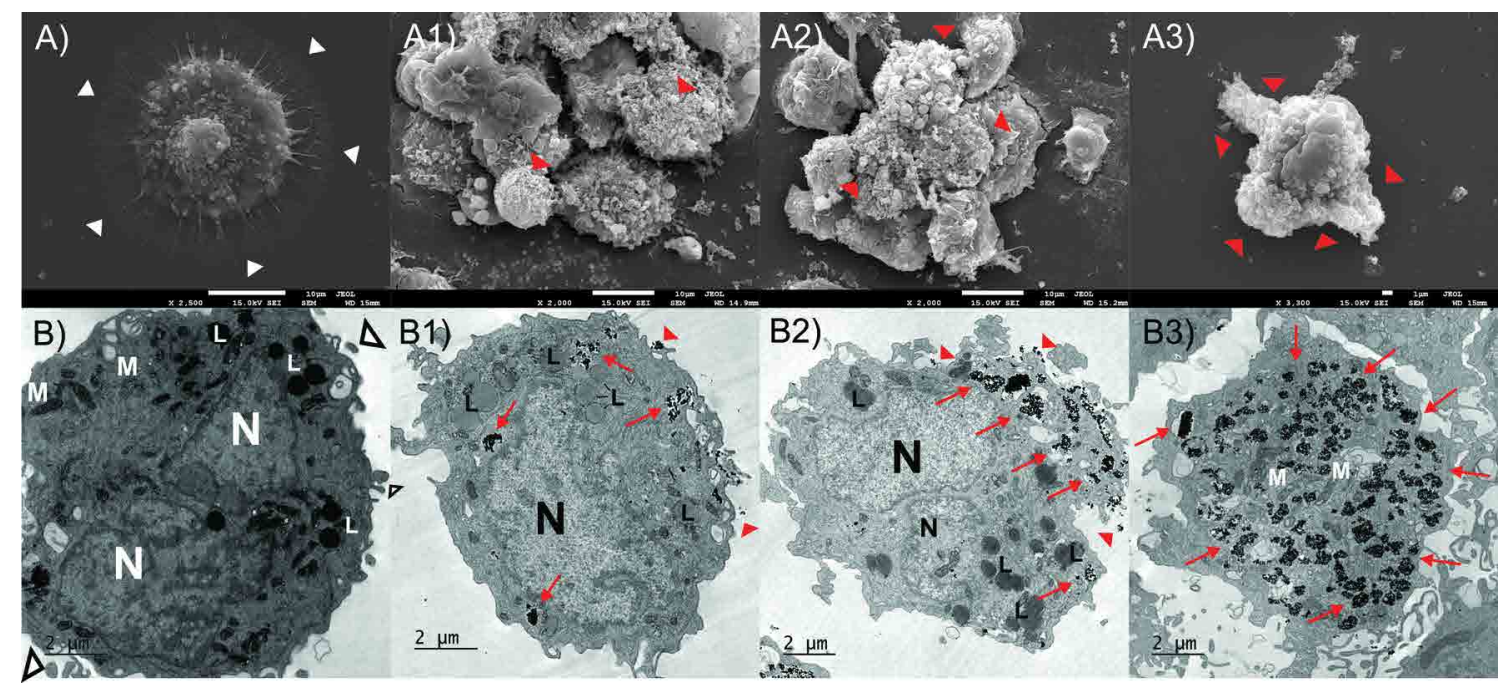

Figure 9: Micrographs of the U-937 cell line after treatment with Magh-RhCit coated with protein corona from human blood serum. A) Micrographs obtained from Scanning Electron Microscopy. A) Control cell; A1) 1 hour; A2) 3 hours; A3) 6 hours. B) Micrographs obtained from Transmission Electron Microscopy. B) Control cell; B1) 1 hour; B2) 3 hours; B3) 6 hours. Nucleus (N), lysosomes (L), Mitochondria (M). Red arrows indicate nanoparticles (NPs) in vesicles. Red arrowheads indicate NPs on the surface of the cell membrane. White arrowheads indicate cell surface extension.
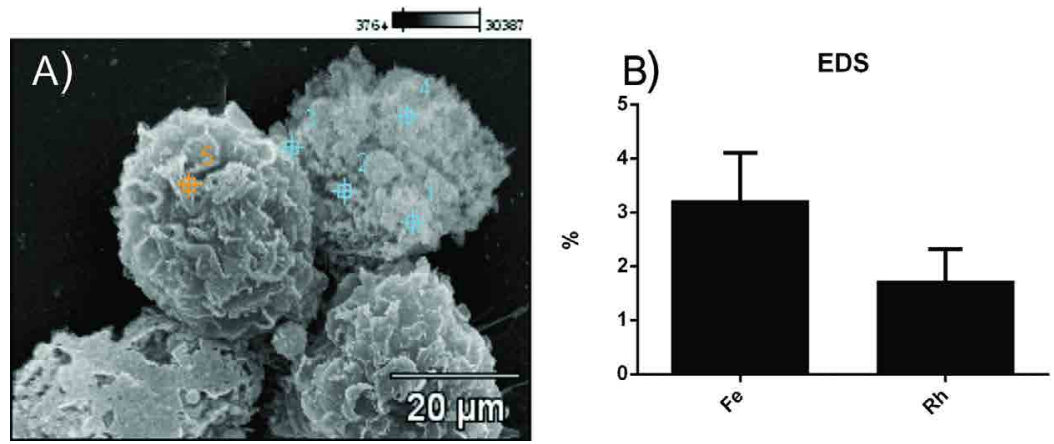

Figure 10: EDS performed on the micrograph of U-937 cells treated with Magh-RhCit. A) Distinct points of U-937 to perform EDS. B) Graphic of the EDS averages obtained in the 5 points of the image. NP/CC-nanoparticle associated with protein corona. 
period (Figure 11B). It was observed that the rhodium component remains bound to NPs even after 72 hours of treatment and with PC formation. This is important because rhodium is the major component of the treatment formulation.

In this study, micrograph results (Figure 9) and analysis of quantitative data (Figures 10 and 11) show that there is strong interaction between Magh-RhCit and macrophages that results in high internalization of NPs in these cells. These results are probably due to the dynamic complement of the protein corona's proteinmediated opsonization, phagocytosis and endocytosis. Walkey et al. [52] have shown that serum-dependent macrophage internalization (with protein corona) is more efficient than serum-independent uptake (without protein corona), since the protein corona is a determining factor for internalization of the nanomaterial by immune system cells.

Figure 12 shows a cell viability plot for strain U-937 after treatment with Magh-RhCit. Over the first 24 hours a decrease in cell viability is observed from the concentration of $100 \mu \mathrm{M}$, which continues to drop with increasing levels of concentration (200 and $300 \mu \mathrm{M})$. At 48 hours of incubation, even the lowest concentration of Magh-RhCit interferes with cell viability, and $300 \mu \mathrm{M}$ causes a greater effect on cell death. At 72 hours of incubation, cell viability decreases considerably. Based on these results, we can state that Magh-RhCit is cytotoxic to the U-937 cell line (Figure 12).
According to Corbo et al. [53], the formation of a PC can increase specificity of internalization, particularly in professional and nonprofessional phagocytic cells, such as macrophages and endothelial cells, causing an increased risk of cytoplasmic and systemic toxicity.

Studies show that the protein corona mitigates the cytotoxic effects of NPs [54-56]. This is probably due to the effect of the PC on protecting cells from direct contact with the bare surface of NPs. The coating with proteins from biological fluids may increase NP stability, a fact identified in our study (Figure 5). This coating is also important from the viewpoint of cellular toxicity. On the other hand, since proteins are adsorbed on the surface of NPs, they may undergo conformational changes in secondary and tertiary structure, resulting in unnatural protein configurations that trigger phagocytosis and potential inflammatory reactions [5761]. Here we show that U-937 cell viability is compromised after treatment with the Magh-RhCit protein corona. However, further studies need to be performed on M1 and M2 type macrophages. Macrophages polarized in M1 are considered proinflammatory macrophages involved in host defense. M2 macrophages, however, exhibit anti-inflammatory and healing properties, but also promote tumor growth [60]. Studies with other nanomaterials point to a preferential absorption of NPs by M2-type macrophages, inhibiting tumor growth [62-64]. Understanding the performance of the
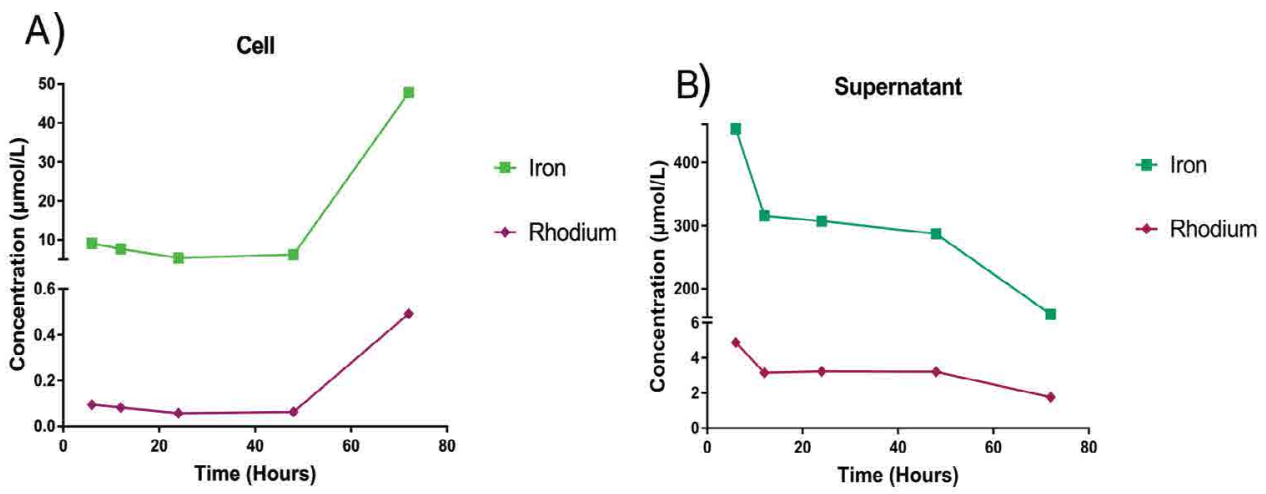

Figure 11: Iron and rhodium quantification by ICP/OES. A) Internalized iron (blue line) and rhodium (green line) concentration ( $\mu \mathrm{M} / \mathrm{L}$ ) in the Magh$\mathrm{RhCit}$ treated $(200 \mu \mathrm{M}$ rhodium citrate $/ 2.9 \mathrm{mmol} / \mathrm{L})$ cell line U-937 coated with human blood serum protein corona. B) Quantification ( $\mu \mathrm{M} / \mathrm{L})$ of the non-internalized iron (red line) and rhodium (purple line) in cells. Cells were exposed to periods of 6, 12, 24 and 72 hours.

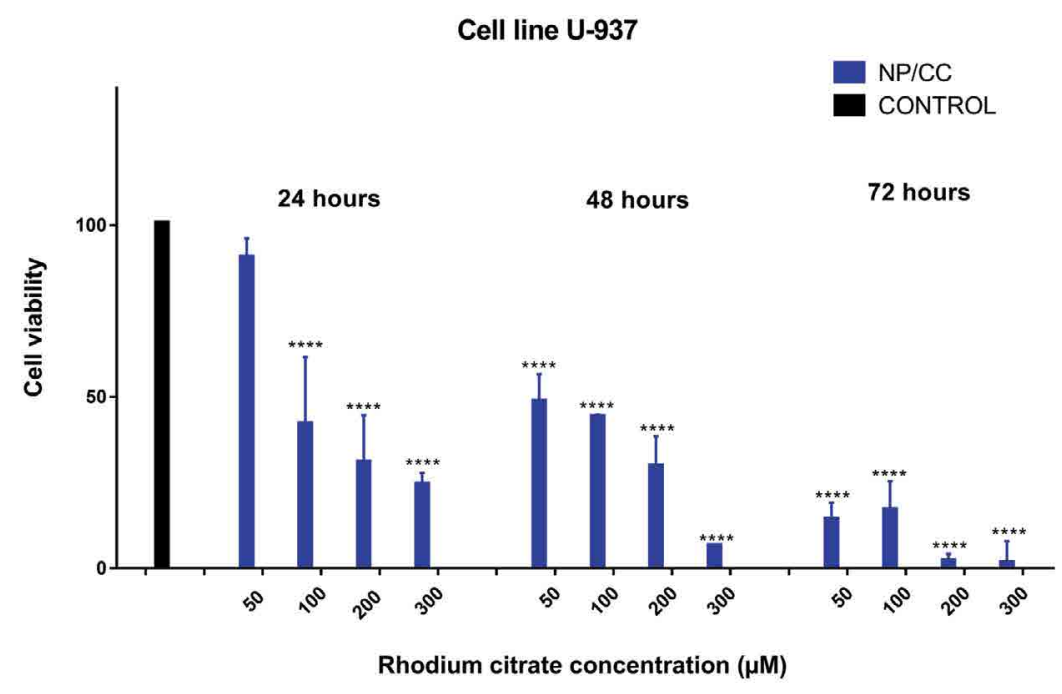

Figure 12: Human macrophages' (U-937) viability after 24, 48 and 72 hours of treatment with Magh-RhCit coated with protein corona from human blood serum. Rhodium citrate was used at the concentrations of 50, 100, 200 and $300 \mu \mathrm{M}$. ${ }^{* * * *} \mathrm{p}<0.0001$. 
Magh-RhCit nanoparticle in macrophages of the M2 type (in vitro and in vivo) may offer new therapeutic approaches for the treatment of tumors.

\section{CONCLUSION}

From the results obtained and evaluated, we conclude that, depending on the state of the NPs, their properties are altered, allowing agglomeration or dispersion. Human blood serum alters the characteristics of NPs, making them less polydisperse, larger and with lower zeta potential. These parameters depend on factors such as incubation time and temperature. These changes can be explained due to the formation of the protein corona. In addition, NPs in the absence of human blood serum (without protein corona) are unstable, precipitate and form large agglomerates. We identified the adsorbed proteins on the surface of Magh-RhCit that most promote opsonization, phagocytosis and endocytosis in the cells of the immune system. The findings are relevant because studies conducted with this type of nanomaterial have focused on its use as a treatment for cancer. One of the desirable characteristics for this purpose is that the NPs should reach the tumor target at therapeutic concentrations. These findings clarify which human blood serum proteins adsorb to Magh-RhCit as well as their interaction in macrophages. Further studies need to be performed to elucidate how this complex may favor tumor treatment.

\section{FUNDING}

This work was financially supported by the Coordination of Improvement of Higher Level Personnel (CAPES), National Council for Scientific and Technological Development (CNPq), Foundation for Research Support of the Federal District (FAPDF). Funding for LC-MS/MS was provided by grant grants 0439/11 and 0694/13 from Financiadora de Estudos e Projetos (FINEP) to M.V.S.

\section{ETHICS APPROVAL AND CONSENT TO PARTICIPATE}

The serum used was collected at the University of Brasilia with the approval of the Research Ethics Committee (CAAE: 59103416.9.0000.0030; Number: 1,936,932).

\section{AUTHORS' CONTRIBUTIONS}

W.F.L and S.N.B. conceived and designed the experiments. N.V.C and W.F.L performed the experiments. S.N.B, N.L.C, M.H.S, W.F, M.V.S, M.A.R and W.F.L analyzed the data. W.F.L drafted and wrote the manuscript. All authors read and approved the final manuscript.

\section{CONSENT FOR PUBLICATION}

All authors agreed to submit this manuscript.

\section{COMPETING INTERESTS}

The authors declare that they have no competing interests.

\section{AVAILABILITY OF DATA AND MATERIAL}

The datasets used and/or analyzed during the current study are available from the corresponding author on reasonable request.

\section{ACKNOWLEDGEMENTS}

We would like to thank the Institute of Biological Sciences of the University of Brasilia-UnB, the LabMic laboratory of the University of Goiás-UFG, the development agencies CAPES, CNPq, FINEP and FAPDF. Dr. Jaques M. F. Souza was very helpful in protein identification experiments.

\section{REFERENCES}

1. Corbo C, Molinaro R, Parodi A, Salvatore F, Tasciotti E. The impact of nanoparticle protein corona on cytotoxicity, immunotoxicity and target drug delivery. Nanomedicine. 2016;11(1):81-100.

2. Akhter MH, Rizwanullah M, Ahmad J, Ahsan MJ, Mujtaba MA, Amin S, et al. Nanocarriers in advanced drug targeting: setting novel paradigm in cancer therapeutics. Artif Cells Nanomed Biotechnol. 2018;46(5):873-884.

3. Lima-Tenorio MK, Pineda EAG, Ahmad NM, Fessi H, Elaissari A. Magnetic nanoparticles: In vivo cancer diagnosis and therapy. Int J Pharma. 2015;493(1-2):313-327.

4. Némethová V, Buliaková B, Mazancová P, Bábelová A, Šelc M, Moravlíková D, et al. Intracellular uptake of magnetite nanoparticles: a focus on physico-chemical characterization and interpretation of in vitro data. Mat Scie Eng: C. 2017;70:161-168.

5. Escamilla-Rivera, V, Uribe-Ramirez M, Gonzalez-Pozos S, Lozano O, Lucas S, De Vizcaya-Ruiz A, et al. Protein corona acts as a protective shield against Fe3O4-PEG inflammation and ROS-induced toxicity in human macrophages. Toxicol Lett. 2016;240(1):172-184.

6. Sukhanova A, Bozrova S, Sokolov P, Berestovoy M, Karaulov A, Nabiev, I, et al. Dependence of nanoparticle toxicity on their physical and chemical properties. Nanoscale Res Lett. 2018;13(1):44.

7. Carneiro ML, Nunes ES, Peixoto RC, Oliveira RG, Lourenço LH, da Silva IC, et al. Free Rhodium (II) citrate and rhodium (II) citrate magnetic carriers as potential strategies for breast cancer therapy. J Nanobiotechnol. 2011;9(1):11.

8. MacParland SA, Tsoi KM, Ouyang B, Ma XZ, Manuel J, Fawaz A, et al. Phenotype determines nanoparticle uptake by human macrophages from liver and blood. ACS Nano. 2017;11(3):2428-2443.

9. Wilhelm S, Tavares AJ, Dai Q, Ohta S, Audet J, Dvorak HF, et al. Analysis of nanoparticle delivery to tumours. Nat Rev Mat. 2016;1(5):16014.

10. Neagu M, Piperigkou Z, Karamanou K, Engin AB, Docea AO, Constantin C, et al. Protein bio-corona: critical issue in immune nanotoxicology. Arch Toxicol. 2017;91(3):1031-1048.

11. Hu Z, Zhao L, Zhang H, Zhang Y, Wu RA, Zou H, et al. The on-bead digestion of protein corona on nanoparticles by trypsin immobilized on the magnetic nanoparticle. J Chromatogr A. 2014;1334:55-63.

12. Casals E, Pfaller T, Duschl A, Oostingh GJ, Puntes VF. Hardening of the nanoparticle-protein corona in metal $(\mathrm{Au}, \mathrm{Ag})$ and oxide $\left(\mathrm{Fe}_{3} \mathrm{O}_{4}\right.$, $\mathrm{CoO}$, and $\mathrm{CeO}_{2}$ ) nanoparticles. Small. 2011;7(24):3479-3486.

13. Neagu M, Piperigkou Z, Karamanou K, Engin AB, Docea AO, Constantin C, et al. Protein bio-corona: critical issue in immune nanotoxicology. Arch Toxicol. 2017;91(3):1031-1048.

14. Fleischer CC, Payne CK. Nanoparticle-cell interactions: molecular structure of the protein corona and cellular outcomes. Acc Chem Res. 2014;47(8):2651-2659.

15. Walkey CD, Chan WC. Understanding and controlling the interaction of nanomaterials with proteins in a physiological environment. Chem Soc Rev. 2012;41(7):2780-2799.

16. Yan Y, Gause KT, Kamphuis MM, Ang CS, O’Brien-Simpson NM, Lenzo JC, et al. Differential roles of the protein corona in the cellular 
uptake of nanoporous polymer particles by monocyte and macrophage cell lines. ACS Nano. 2013;7(12):10960-10970.

17. MacParland SA, Tsoi KM, Ouyang B, Ma XZ, Manuel J, Fawaz A, et al. Phenotype determines nanoparticle uptake by human macrophages from liver and blood. ACS Nano. 2017;11(3), 2428-2443.

18. Lunov O, Syrovets T, Loos C, Beil J, Delacher M, Tron K, et al. Differential uptake of functionalized polystyrene nanoparticles by human macrophages and a monocytic cell line. ACS Nano. 2011;5(3): 1657-1669.

19. Foroozandeh P, Aziz AA. Merging worlds of nanomaterials and biological environment: factors governing protein corona formation on nanoparticles and its biological consequences. Nanoscale Research Letters. 2015;10(1):221.

20.Kuchma EA, Zolotukhin PV, Belanova AA, Soldatov MA, Lastovina TA, Kubrin SP, et al. Low toxic maghemite nanoparticles for theranostic applications. Int J Nanomed. 2017;12:6365.

21. Carneiro MLB, Peixoto RC, Joanitti GA, Oliveira RG, Telles LA, Miranda-Vilela AL, et al. Antitumor effect and toxicity of free rhodium (II) citrate and rhodium (II) citrate-loaded maghemite nanoparticles in mice bearing breast cancer. J Nanobiotechnol. 2013;11(1):4.

22. Carneiro ML, Lopes CA, Miranda-Vilela AL, Joanitti GA, da Silva IC, Mortari MR, et al. Acute and subchronic toxicity of the antitumor agent rhodium (II) citrate in Balb/c mice after intraperitoneal administration. Toxicol Rep. 2015;2:1086-1100.

23. Peixoto RCA, Miranda-Vilela AL, de Souza Filho J, Carneiro MLB, Oliveira RG, da Silva MO, et al. Antitumor effect of free rhodium (II) citrate and rhodium (II) citrate-loaded maghemite nanoparticles on mice bearing breast cancer: a systemic toxicity assay. Tumor Biol. 2015;36(5):3325-3336.

24. Chaves NL, Lopes CAP, Carneiro MLB, de Souza AR, da Silva $\mathrm{MO}$, Corrêa JR, et al. Rhodium citrate associated with maghemite nanoparticles causes DNA fragmentation independently of caspases 3 and mediated by reactive oxygen species. J Nanomed Nanotech. 2015;6(5):1.

25.da Silva Nunes E, Carneiro MLB, de Oliveira RGS, Báo SN, de Souza AR. Colloidal stability, surface characterisation and intracellular accumulation of Rhodium (II) citrate coated superparamagnetic iron oxide nanoparticles in breast tumour: a promising platform for cancer therapy. J Nanopart Res. 2013;15(6):1683.

26.Shrestha S, Jiang P, Sousa MH, Morais PC, Mao Z, Gao C, et al. Citratecapped iron oxide nanoparticles impair the osteogenic differentiation potential of rat mesenchymal stem cells. J Mater Chem B. 2016;4(2):245256.

27. Hunter Robert J. Zeta potential in colloid science: principles and applications. Academic Press. 2013;2.

28.Drummond AL, Feitoza NC, Duarte GC, Sales MJA, Silva LP, Chaker JA, et al. Reducing size-dispersion in one-pot aqueous synthesis of maghemite nanoparticles. J Nanoscie Nanotechnol. 2012;12(10):80618066.

29.Sharma A, Cornejo C, Mihalic J, Geyh A, Bordelon DE, Korangath P, et al. Physical characterization and in vivo organ distribution of coated iron oxide nanoparticles. Sci Rep. 2018;8(1):4916.

30.Vasti C, Bedoya DA, Rojas R, Giacomelli CE. Effect of the protein corona on the colloidal stability and reactivity of LDH-based nanocarriers. J Mat Chem B. 2016;4(11):2008-2016.

31. Cedervall T, Lynch I, Foy M, Berggård T, Donnelly SC, Cagney G, et al. Detailed identification of plasma proteins adsorbed on copolymer nanoparticles. Angew Chem International Edition. 2007;46(30):57545756.
32.Casals E, Pfaller T, Duschl A, Oostingh GJ, Puntes V. Time evolution of the nanoparticle protein corona. ACS Nano. 2010;4(7):3623-3632.

33.Monopoli MP, Walczyk D, Campbell A, Elia G, Lynch I, Baldelli Bombelli F, et al. Physical-chemical aspects of protein corona: relevance to in vitro and in vivo biological impacts of nanoparticles. J Am Chem Soc. 2011;133(8):2525-2534.

34.Walczyk D, Bombelli FB, Monopoli MP, Lynch I, Dawson KA. What the cell "sees" in bionanoscience. J Am Chem Soc. 2010;132(16):57615768.

35.Fleischer CC, Kumar U, Payne CK. Cellular binding of anionic nanoparticles is inhibited by serum proteins independent of nanoparticle composition. Biomater Sci. 2013;1(9):975-982.

36.Adkins JN, Varnum SM, Auberry KJ, Moore RJ, Angell NH, Smith $\mathrm{RD}$, et al. Toward a human blood serum proteome: analysis by multidimensional separation coupled with mass spectrometry. Mol Cell Proteomics. 2002;1(12):947-955.

37. Pieper R, Gatlin CL, Makusky AJ, Russo PS, Schatz CR, Miller SS, et al. The human serum proteome: Display of nearly 3700 chromatographically separated protein spots on two-dimensional electrophoresis gels and identification of 325 distinct proteins. Proteom: Inter Ed. 2003;3(7):1345-1364.

38.Barrán-Berdón AL, Pozzi D, Caracciolo G, Capriotti AL, Caruso G, Cavaliere $\mathrm{C}$, et al. Time evolution of nanoparticle-protein corona in human plasma: relevance for targeted drug delivery. Langmuir. 2013;29(21):6485-6494.

39.Rahman M, Laurent S, Tawil N, Yahia Le, Mahmoudi M. Interações proteína-nanopartícula. Berlim, Alemanha: Springer. 2013;21-44.

40.Karmali PP, Simberg D. Interactions of nanoparticles with plasma proteins: implication on clearance and toxicity of drug delivery systems. Expert Opin Drug Delivery. 2011;8(3):343-357.

41. Manning G, Whyte DB, Martinez R, Hunter T, Sudarsanam S. The protein kinase complement of the human genome. Science. 2002;298(5600):1912-1934.

42.Zhu Y, Yang Q, Yang M, Zhan X, Lan F, He J, et al. Protein corona of magnetic hydroxyapatite scaffold improves cell proliferation via activation of mitogen-activated protein kinase signaling pathway. ACS Nano. 2017;11(4):3690-3704.

43.Huber R, Carrell RW. Implications of the three-dimensional structure of. alpha. 1-antitrypsin for structure and function of serpins. Biochemistry. 1989;28(23):8951-8966.

44.Kim HR, Andrieux K, Delomenie C, Chacun H, Appel M, Desmaële $\mathrm{D}$, et al. Analysis of plasma protein adsorption onto PEGylated nanoparticles by complementary methods: 2-DE, CE and Protein Lab on-chip ${ }^{\circledR}$ system. Electrophoresis. 2007;28(13):2252-2261.

45.Kim HR, Andrieux K, Gil S, Taverna M, Chacun H, Desmaële D, et al. Translocation of poly (ethylene glycol-co-hexadecyl) cyanoacrylate nanoparticles into rat brain endothelial cells: role of apolipoproteins in receptor-mediated endocytosis. Biomacromolecules. 2007;8(3):793 799.

46.Peracchia MT, Harnisch S, Pinto-Alphandary H, Gulik A, Dedieu JC, Desmaele D, et al. Visualization of in vitro protein-rejecting properties of PEGylated stealth ${ }^{\circledR}$ polycyanoacrylate nanoparticles. Biomaterials. 1999;20(14):1269-1275.

47. Göppert TM, Müller RH. Adsorption kinetics of plasma proteins on solid lipid nanoparticles for drug targeting. Inte J Pharma. 2005;302(12):172-186

48.Lück M, Paulke B, Schröder W, Blunk T, Müller RH. Analysis of plasma protein adsorption on polymeric nanoparticles with different surface characteristics. J Biomed Mater Res. 1998;39:478-485. 
49.Peracchia MT, Harnisch S, Pinto-Alphandary H, Gulik A, Dedieu JC, Desmaele D, et al. Visualization of in vitro protein-rejecting properties of PEGylated stealth ${ }^{\circledR}$ polycyanoacrylate nanoparticles. Biomaterials. 1999;20(14):1269-1275.

50.Gessner A, Lieske A, Paulke B, Müller RH. Functional groups on polystyrene model nanoparticles: Influence on protein adsorption. J Biomed Mater Res. 2003;65A:319-326.

51. Vroman L, Adams AL, Fischer GC, Munoz PC. Interaction of high molecular weight kininogen, factor XII, and fibrinogen in plasma at interfaces. Blood. 1980;55(1):156-159.

52.Walkey CD, Olsen JB, Guo H, Emili A, Chan WC. Nanoparticle size and surface chemistry determine serum protein adsorption and macrophage uptake. J Am Chem Soc. 2012;134(4):2139-2147.

53.Corbo C, Molinaro R, Parodi A, Salvatore F, Tasciotti E, et al. The impact of nanoparticle protein corona on cytotoxicity, immunotoxicity and target drug delivery. Nanomedicine. 2016;11(1):81-100.

54.Zhang T, Tang M, Yao Y, Ma Y, Pu Y. MWCNT interactions with protein: surface-induced changes in protein adsorption and the impact of protein corona on cellular uptake and cytotoxicity. Int J nanomed. 2019; 14:993-1009.

55.Ge C, Du J, Zhao L, Wang L, Liu Y, Li D, et al. Binding of blood proteins to carbon nanotubes reduces cytotoxicity. Proc Natl Acad Sci. 2011;108(41):16968-16973.

56.Tenzer S, Docter D, Kuharev J, Musyanovych A, Fetz V, Hecht R, et al. Rapid formation of plasma protein corona critically affects nanoparticle pathophysiology. Nat Nanotechnol. 2013;8(10):772-781.
57. Aggarwal P, Hall JB, McLeland CB, Dobrovolskaia MA, McNeil SE. Nanoparticle interaction with plasma proteins as it relates to particle biodistribution, biocompatibility and therapeutic efficacy. Adv Drug Del Rev. 2009;61(6):428-437.

58.Dobrovolskaia MA, McNeil SE. Immunological properties of engineered nanomaterials. Nat Nanotechnol. 2007;2(8):469-478.

59.Dobrovolskaia MA, Aggarwal P, Hall JB, McNeil SE. Preclinical studies to understand nanoparticle interaction with the immune system and its potential effects on nanoparticle biodistribution. Mol Pharmaceutics. 2008;5(4):487-495.

60.Bogart LK, Pourroy G, Murphy CJ, Puntes V, Pellegrino T, Rosenblum $D$, et al. Nanoparticles for imaging, sensing, and therapeutic intervention. ACS Nano. 2014;8(4): 3107-3122.

61. Boraschi D, Duschl A. Nanoparticles and the immune system: safety and effects. Academic Press. 2013.

62.Hoppstädter J, Seif M, Dembek A, Cavelius C, Huwer H, Kraegeloh A, et al. M2 polarization enhances silica nanoparticle uptake by macrophages. Front Pharmacol. 2015;6:55.

63.Zanganeh S, Hutter G, Spitler R, Lenkov O, Mahmoudi M, Shaw A, et al. Iron oxide nanoparticles inhibit tumour growth by inducing pro-inflammatory macrophage polarization in tumour tissues. Nat nanotechnol. 2016;11(11):986.

64.Pang L, Pei Y, Uzunalli G, Hyun H, Lyle LT, Yeo Y. Surface Modification of Polymeric Nanoparticles with M2pep Peptide for Drug Delivery to Tumor-Associated Macrophages. Pharmaceutical Res. 2019;36(4):65. 